\title{
Alat Otomatisasi Pengukur Kadar Vitamin C Dengan Metode Titrasi Asam Basa
}

\begin{abstract}
Dani Ika*
Abstrak : Tujuan yang ingin dicapai dalam penelitian ini adalah untuk menghasilkan alat titrasi sederhana yang mampu mengukur kadar vitamin $\mathrm{C}$ secara otomatis untuk mengurangi tingkat kesalahan pengukuran kadar vitamin $\mathrm{C}$ pada larutan. Metode yang digunakan untuk mengukur kadar vitamin $\mathrm{C}$ adalah metode titrasi asam basa yaitu larutan vitamin $\mathrm{C}$ yang bersifat asam dititrasi oleh larutan $\mathrm{NaOH}$ yang bersifat basa, dimana jumlah asam pada larutan setara dengan jumlah basa. Penelitian ini mengambil dua puluh sampel larutan vitamin $\mathrm{C}$ yang dilarutkan dengan $100 \mathrm{ml}$ aquadest. Data dikumpulkan pada bulan April 2009, data yang diperoleh kemudian dianalisis dan hasilnya dibandingkan dengan hasil pengukuran kadar Vitamin $\mathrm{C}$ pada alat spektrofotometer untuk menentukan ketelitian pada alat ukur kadar vitamin $\mathrm{C}$ dengan menggunakan metode titrasi asam basa.Dari hasil pegujian terhadap alat ukur kadar vitamin $\mathrm{C}$ baik pengontrol mikrokontroller AT89S51, maupun liquid cristal display (LCD) dapat disimpulkan bahwa dengan menggunakan alat kadar vitamin $\mathrm{C}$ metode titrasi asam basa dapat mengukur kadar vitamin $\mathrm{C}$ sesuai dengan hasil perbandingan nilai kadar vitamin $\mathrm{C}$ pada alat spektrofotometer. Pengukuran kadar vitamin $\mathrm{C}$ dengan menggunakan metode titrasi asam basa menunjukkan nilai kesalahan relatif sebesar $1,4601 \%$.
\end{abstract}

Kata kunci: Vitamin $\mathrm{C}$, Titrasi, $\mathrm{pH}$ meter

\section{PENDAHULUAN}

Di muka bumi ini kita mengenal dua jenis sumber energi, yaitu sumber energi yang dapat diperbaharui dan yang tidak dapat diperbaharui. Penggunaan energi secara nasional cenderung pada sumber energi berupa minyak bumi dan gas alam. Yang menjadi masalah di sini yaitu, persediaan sumber energi tersebut semakin menipis dikarenakan sumber energi tersebut tidak dapat diperbaharui. Jika dibiarkan dapat mengancam kelangsungan kehidupan manusia di muka bumi ini.

Untuk mengatasi masalah tersebut maka diperlukan usaha-usaha untuk mencari sumber energi alternatif seperti energi tenaga air, batu bara, geothermal, gas alam, solar cell, dan sel bahan bakar seperti penggunaan biomassa dan lain-lain (Jurnal Nutrino.2009).

Keunggulan dari energi matahari (solar cell) ini dibandingkan dengan sumber energi alternatif lainnya adalah tidak bersifat polutif, berlimpah, bersifat terbarukan, gratis, tidak pernah habis, dan dapat dimanfaatkan baik secara langsung maupun tidak langsung dan merupakan sumber energi sepanjang masa.

Potensi penggunaan energi matahari ini dapat kita manfaatkan untuk penyinaran, pemanas air, pengering hasil pertanian dan perikanan, perkembangan tumbuhan, sebagai bahan bakar, penghasil tenaga listrik dan lain-lain.

Sejauh ini, pemanfaatan sumber energi matahari yang paling banyak yaitu untuk pemanas. Pemanas air dengan menggunakan tenaga matahari atau lebih dikenal dengan sebutan solar water heater system yang belakangan ini banyak dibicarakan. Pemanas air ini memanfaatkan energi dari alam yang tidak akan habis.

Bandingkan dengan pemanas air yang menggunakan tenaga listrik, gas atau minyak bumi. Seperti yang kita ketahui saat ini suplai listrik sangat terbatas, apalagi di beberapa daerah masih mengalami krisis listrik. Selain itu dari sisi ekonomi, biaya yang dikeluarkan untuk membayar tagihan listrik juga semakin tinggi untuk setiap tahunnya. Sama halnya dengan pemanas air yang menggunakan energi gas, sebagaimana kita ketahui bahwa

\footnotetext{
${ }^{(*)}$ Pemerhati fisika
} 
minyak bumi dan gas merupakan sumber daya alam yang tidak dapat diperbaharui, yang tentunya akan habis apabila digunakan secara terus-menerus.

Berdasarkan hal tersebut di atas, kita dapat memanfaatkan energi dari radiasi sinar matahari untuk suatu sistem pemanas air yang dapat digunakan untuk memanaskan air, untuk keperluan kebutuhan mandi keluarga. Oleh karena itu diperlukan suatu proses untuk mencapai ke arah itu. Untuk mendukung proses ini diperlukan suatu alat yang bisa menaikan temperatur air dari normal ke temperatur yang lebih panas. Untuk keperluan ini, dibutuhkan suatu alat pemanas air yang dinamakan kolektor. Kolektor di sini berfungsi sebagai penyerap dan penyimpan panas dari radiasi sinar matahari.

Beberapa penelitian tentang pemanas air menggunakan energi dari radiasi matahari ini telah dilakukan di antaranya yaitu oleh Subhan Hamka dengan judul penelitian "Pemanas Air Energi Surya Dengan Cermin Datar Sebagai Reflektor Cahaya Dengan Pipa Hitam Sebagai Medium Air" (2005) dan Ferry Eka Budi Setiawan dengan judul penelitian "Perancangan Alat Pemanas Air Tenaga Surya" (2006).

Terkait dengan hasil dari penelitian Subhan Hamka hanya terdapat satu kolektor panas menggunakan pipa tembaga dengan ukuran kolektor $1 \mathrm{~m} \times 0,5 \mathrm{~m}$, selain itu menggunakan cermin sebagai reflektor sinar matahari. Penelitian yang sama dilakukan oleh Ferry Eka Budi Setiawan, akan tetapi yang berbeda dengan peneliti sebelumnya adalah tidak menggunakan cermin sebagai reflektor cahaya. Dari kedua penelitian di atas hanya menargetkan temperatur yang akan dicapai melalui pemanasan kolektor untuk jangka waktu tertentu. Subhan Hamka menargetkan temperatur mencapai $80^{\circ}$ dan Ferry Eka Budi Setiawan $70^{\circ}$. Temperatur ini tidak diperoleh dari pengamatan dan pengukuran temperatur secara langsung, akan tetapi hanya berdasarkan perhitungan teoritik.

Kekurangan lain dari ke dua peneliti sebelumnya yaitu kolektor tidak dipasang di dalam kotak/box dari kaca transparan sehingga diperkirakan terjadi kerugian kalor dari kolektor ke lingkungan. Selain itu keduanya tidak menjelaskan berapa banyak air panas yang mereka peroleh.

Merujuk dari penelitian yang telah ada, penulis mencoba untuk mendesain ulang alat pemanas air ini dengan mengambil judul "Desain Sistem Pemanas Air Menggunakan Radiasi Sinar Matahari". Di sini penulis akan membuat kolektor sebanyak dua buah dengan ukuran yang sama dan dibuat bertingkat untuk mendukung aliran debit air dari tandon air dingin ke tandon air panas. Kotak untuk kolektor dibuat dari kaca transparan sehingga sinar matahari dapat memanaskan kolektor dari arah mana saja. Pengukuran temperatur dilakukan setiap 30 menit sekali. Pengambilan data hanya dilakukan pada saat cuaca terang saja. Untuk memaksimalkan temperatur kolektor, bahan yang digunakan untuk kolektor yaitu aluminium bukan tembaga, karena aluminium lebih cepat proses pemanasannya, tidak mudah karatan (korosi) dan harganya relatif lebih murah dibanding harga tembaga. Dari desain ini diharapkan temperatur yang akan diperoleh mencapai maksimum.

\section{KAJIAN TEORI Vitamin}

Vitamin adalah zat-zat organik kompleks yang dibutuhkan dalam jumlah sangat kecil dan pada umumnya tidak dapat dibentuk oleh tubuh. Vitamin termasuk kelompok zat pengatur pertumbuhan dan pemeliharaan kehidupan. Tiap vitamin mempunyai tugas spesifik dalam tubuh. (Almatsier, 2003).

Hampir semua vitamin yang kita kenal sekarang telah berhasil diidentifikasi sejak tahun 1930. Vitamin pada umumnya dapat dikelompokkan menjadi dua golongan utama yaitu vitamin yang larut dalam lemak yang meliputi vitamin $\mathrm{A}, \mathrm{D}, \mathrm{E}$, dan $\mathrm{K}$ dan vitamin yang larut dalam air yang terdiri dari vitamin C dan vitamin B (Winarno, 2002). 


\section{Vitamin C}

Penyakit scurvy telah dikenal sejak abad ke-15, yaitu penyakit yang menyebabkan pucat, rasa lelah berkepanjangan diikuti oleh pendarahan gusi, pendarahan di bawah kulit, edema, tukak, dan pada akhirnya kematian. Pada tahun 1750, Lind, seorang dokter dari Skotlandia menemukan bahwa scurvy dapat dicegah dan diobati dengan memakan jeruk.

Baru pada tahun 1923 Szent-Gyorgy dan C. Glenn King berhasil mengisolasi antiskorbut dari jaringan adrenal, jeruk dan kol yang dinamakan vitamin C. Zat ini kemudian berhasil disintesis pada tahun1933 oleh Haworth Hist sebagai asam askorbat (Almatsier, 2003)

\section{Fungsi vitamin $\mathrm{C}$ dalam tubuh}

Vitamin C mempunyai banyak fungsi dalam tubuh, sebagai koenzim atau kofaktor. Asam askorbat adalah bahan yang kuat kemampuan reduksinya dan bertindak sebagai antioksidan dalm reaksi-reaksi hidroksilasi. Beberapa turunan vitamin $\mathrm{C}$ (seperti asam eritrobik dan askorbik palmitat) digunakan sebagai antioksidan di dalam industri pangan untuk mencegah proses menjadi tengik, perubahan warna (browning) pada buah-buahan dan untuk mengawetkan daging.

Vitamin C pada tubuh manusia juga berfungsi sebagai sintesis kolagen, sintesis karnitin, noradrenalin, serotonin, adsorbsi dan metabolisme besi,absorbsi kalsium, mencegah infeksi serta mencegah kanker dan penyakit jantung (Almatsier, 2003)

Asam askorbat (vitamin C) sangat dibutuhkan oleh organ tubuh pada biologi manusia. Buah-buahan yang segar, sayuran dan beberapa tablet suplemen asam askorbat sintetik memenuhi segala kebutuhan tubuh. Di mana stress, merokok, infeksi, dan luka bakar membutuhkan cadangan asam askorbat dalam tubuh dan suplemen asam askorbat dalam jumlah besar (Naidu, 2003).

Berikut ini adalah tabel kandungan asam askorbat yang terdapat pada buah dan sayur-sayuran

Tabel 1. Tabel kandungan asam askorbat pada makanan

\begin{tabular}{|c|c|c|c|}
\hline fruits & $\begin{array}{c}\mathrm{mg} / 100 \mathrm{~g} \\
\text { edible }\end{array}$ & Vegetable & $\begin{array}{c}\mathrm{mg} / 100 \mathrm{~g} \\
\text { edible }\end{array}$ \\
\hline banana & $8-16$ & Onion & $10-15$ \\
\hline Mango & $10-15$ & Tomato & $10-20$ \\
\hline pineaple & $15-25$ & Egg plant & $15-20$ \\
\hline Papaya & 39 & Radish & 25 \\
\hline Orange & $30-50$ & Spinach & $35-40$ \\
\hline Strawberry & $40-70$ & Cabbage & $30-70$ \\
\hline $\begin{array}{c}\text { Currant } \\
\text { Black }\end{array}$ & $150-200$ & Caulitflower & $50-70$ \\
\hline Rose Hips & $250-800$ & Broccoli & $80-90$ \\
\hline
\end{tabular}

Sintesis adalah salah satu cara untuk mebuat vitamin $\mathrm{C}$ olahan, dengan cara menggabungkan Vitamin $\mathrm{C}$ pada buah dengan zat yang lainnya. 


\section{Sifat fisika kimia Vitamin C}

Asam askorbat atau vitamin $\mathrm{C}$ berbentuk kristal putih, tidak berbau, meleleh pada suhu $190^{\circ}-192^{\circ}$ C. Rasanya sedikit masam, mudah larut dalam air. Oleh karena itu, dalam ektraksi tidak memerlukan pemanasan seperti pada ektraksi analisa gula reduksi. Vitamin C stabil dalam bentuk kristal, namun mudah teroksidasi dalam larutan menjadi dehidro askorbat yang juga memiliki fungsi fisiologis dalam tubuh manusia, namun tidak memiliki kemampuan sebagai zat anti sariawan.

Vitamin $C$ yang diekstrak dari sari buah lemon yang dikenal sebagai zat pereduksi yang mereduksi larutan Fehling, garam Perak Nitrat dan Kalium Permanganat. Penyimpanan yang kurang baik mengakibatkan Vitamin $\mathrm{C}$ mudah teroksidasi. Vitamin $\mathrm{C}$ juga mudah teroksidasi dalam larutan 2,6 Dicchlorophenolindophenol dan oksigen dalam larutan bersifat basa. Analisa vitamin $\mathrm{C}$ ada beberapa macam baik metode volumetric (titrasi) maupun spectrophotometri (Wijanarko, 2002).

\section{Analisa Vitamin C}

Terdapat beberapa metode untuk mengetahui kadar vitamin $\mathrm{C}$ pada suatu bahan pangan. Diantaranya adalah metode titrasi dan metode spektrofotometri.

\section{a. Metode Titrasi}

1. Iodium

Metode ini paling banyak digunakan, karena murah, sederhana, dan tidak memerlukan peralatan laboratorium yang canggih. titrasi ini memakai Iodium sebagai oksidator yang mengoksidasi vitamin $\mathrm{C}$ dan memakai amilum sebagai indikatornya. (Wijanarko, 2002).

2. Metode Titrasi 2,6 D (Dichloroindophenol)

Metode ini menggunakan 2,6 D dan menghasilkan hasil yang lebih spesifik dari titrasi yodium. Pada titrasi ini, persiapan sampel ditambahkan asam oksalat atau asam metafosfat, sehingga mencegah logam katalis lain mengoksidasi vitamin C. Namun, metode ini jarang dilakukan karena harga dari larutan 2,6 D dan asam metafosfat sangat mahal (Wijanarko, 2002).

\section{Titrasi Asam-Basa}

Titrasi Asam Basa merupakan contoh analisis volumetri, yaitu, suatu cara atau metode, yang menggunakan larutan yang disebut titran dan dilepaskan dari perangkat gelas yang disebut buret. Bila larutan yang diuji bersifat basa maka titran harus bersifat asam dan sebaliknya. Untuk menghitungnya kadar vitamin $\mathrm{C}$ dari metode ini adalah dengan mol $\mathrm{NaOH}=$ mol asam Askorbat (Sastrohamidjojo, 2005).

\section{Metode Spektrofotometri}

Pada metode ini, larutan sampel (vitamin C) diletakkan pada sebuah kuvet yang disinari oleh cahaya UV dengan panjang gelombang yang sama dengan molekul pada vitamin C yaitu $269 \mathrm{~nm}$. Analisis menggunakan metode ini memiliki hasil yang akurat. Karena alasan biaya, metode ini jarang digunakan (Sudarmaji, 2007).

\section{Titrasi Asam Basa}

Titrasi adalah suatu proses atau prosedur dalam analisis volumetric di mana suatu titran atau larutan standar (yang telah diketahui konsentrasinya) diteteskan melalui buret ke larutan lain yang dapat bereaksi dengannya (belum diketahui konsentrasinya) hingga tercapai titik ekuivalen atau titik akhir. Artinya, zat yang ditambahkan tepat bereaksi dengan zat yang ditambahi. Zat yang akan ditentukan kadarnya disebut sebagai "titrant" dan biasanya diletakan di dalam Erlenmeyer, sedangkan zat yang telah diketahui 
konsentrasinya disebut sebagai "titer" dan biasanya diletakkan di dalam "buret". Baik titer maupun titrant biasanya berupa larutan (Almatsier, 2003).

Berikut ini adalah syarat-syarat yang diperlukan agar proses titrasi berhasil :

1. Konsentrasi titran $(\mathrm{NaOH})$ harus diketahui. Larutan seperti ini disebut larutan standar

2. Titik ekuivalen harus diketahui. Indikator yang memberikan perubahan warna, atau sangat dekat dengan titik ekuivalen yang sering digunakan. Salah satunya dengan mengetahui perubahan warna larutan pada saat proses titrasi berlangsung. Titik pada saat indikator berubah warna disebut titik akhir.

3. Volume titran yang dibutuhkan untuk mencapai titik ekuivalen harus diketahui setepat mungkin

Proses titrasi asam basa sering dipantau dengan penggambaran $\mathrm{pH}$ larutan yang dianalisis sebagai fungsi jumlah titran yang ditambahkan. Gambar yang diperoleh tersebut disebut kurva $\mathrm{pH}$, atau kurva titrasi yang di dalamnya terdapat titik ekuivalen, yaitu titik dimana titrasi dihentikan (Sastrohamidjodjo, 2005).

\section{Prinsip Titrasi Asam Basa}

Titrasi asam basa akan menjadi setimbang $(\mathrm{pH} 7)$ apabila jumlah asam setara dengan jumlah basa. Kesetimbangan asam basa adalah salah satu dari ketentuan yang terjadi pada hukum alam yang mendasari penciptaan dan keteraturan makromos.

Titrasi asam basa melibatkan asam maupun basa sebagai titer ataupun titrant. Titrasi asam basa berdasarkan reaksi penetralan. Kadar larutan asam ditentukan dengan menggunakan larutan basa dan sebaliknya. Titrant ditambahkan titer sedikit demi sedikit sampai mencapai keadaan ekuivalen (artinya secara stoikiometri titrant dan titer tepat habis bereaksi). Keadaan ini disebut sebagai "titik ekuivalen".

Pada saat titik ekuivalent ini maka proses titrasi dihentikan, kemudian kita mencatat volume titer yang diperlukan untuk mencapai keadaan tersebut. Dengan menggunakan data volume titrant, volume dan konsentrasi titer maka kita bisa menghitung kadar titrant (Day, 1986).

\section{Sensor Konduktivitas}

Sensor adalah jenis tranduser yang digunakan untuk mengubah besaran mekanis, magnetis, panas, sinar, dan kimia menjadi tegangan dan arus listrik. Sensor sering digunakan untuk pendeteksian pada saat melakukan pengukuran atau pengendalian. Beberapa jenis sensor yang banyak digunakan dalam rangkaian elektronik antara lain sensor cahaya, sensor suhu, dan sensor tekanan (Tim Fakultas Teknik, 2003).

Sensor secara umum didefinisikan sebagai alat yang mampu menangkap fenomena fisika atau kimia kemudian mengubahnya menjadi sinyal elektrik baik arus listrik ataupun tegangan. Ada dua jenis sensor, yaitu 1) Sensor fisika, untuk mendeteksi besaran suatu besaran berdasarkan hukum-hukum fisika. Contoh sensos fisika adalah sensor cahaya, sensor suara, sensor gaya, sensor kecepatan, sensor percepatan dan sensor suhu. 2) Sensor kimia, alat yang mampu menangkap atau mendeteksi fenomena berupa zat kimia (baik gas maupun cairan) untuk kemudian diubah menjadi sinyal elektrik. Biasanya melibatkan beberapa reaksi kimia. Contoh sensor kimia adalah $\mathrm{p} \underline{\mathrm{H}}$, sensor Oksigen, sensor ledakan, dan sensor gas. Sensor konduktivitas merupakan salah satu jenis sensor kimia, dikarenakan 
sensor konduktivitas memiliki fungsi untuk mendeteksi nilai konduktivitas suatu bahan atau unsur kimia $(\mathrm{NaOH})$ pada suatu cairan.

Ada dua bagian dalam sensor kimia, yaitu bagian pertama sebagai bagian penerima berfungsi menyeleksi dan mengubah sifat kimia yang dideteksinya menjadi energi yang bisa diukur oleh bagian transducer. Sedangkan bagian kedua adalah transducer yang berfungsi mengubah energi yang membawa sifat sifat kimia tersebut menjadi sinyal elektrik. Jika bagian penerima merupakan bagian yang mampu membedakan zat yang akan dikenalinya, maka bagian transducer ini bukanlah bagian yang mampu membedakan sifat sifat kimia.

Karakteristik sensor kimia ditentukan dari sejauh mana sensor tersebut memiliki kemampuan yang baik dalam mengenali zat yang ingin dideteksinya. Kemampuan mendeteksi zat tersebut meliputi:

1. Sensitifitas, yaitu ukuran seberapa sensitif sensor mengenali zat yang dideteksinya. Sensor yang baik akan mampu mendeteksi zat meskipun jumlah zat tersebut sangat sedikit dibandingkan gas disekelilingnya. Sebagai gambaran sebuah riset dengan menggunakan material nano porous terhadap gas $\mathrm{NO}_{2}$ sudah mampu mendeteksi gas $\mathrm{NO}_{2}$ hanya dengan jumlah $300 \mathrm{ppb}$ (part per billion), artinya sejumlah 300 partikel $\mathrm{NO}_{2}$ yang ada dalam 1 milyar partikel udara sudah bisa membuat sensor ini mendeteksi keberadaannya.

2. Selektifitas, yaitu sejauh mana sensor memiliki kemampuan menyeleksi gas atau cairan yang ingin dideteksinya. Sifat ini tidak kalah penting dengan senitifitas mengingat gas atau cairan yang dideteksi tentunya akan bercampur dengan zat lain yang ada disekelilingnya.

3. Waktu respon dan waktu recovery, yaitu waktu yang dibutuhkan sensor untuk mengenali zat yang dideteksinya.Semakin cepat waktu respon dan waktu recoveri maka semakin baik sensor tersebut. Beberapa gas berbahaya bahkan dapat sangat cepat bereaksi dengan tubuh manusia yang dapat berakibat sangat fatal seperti gas $\mathrm{CO} 2$ atau NO2 yang dalam hitungan dibawah 5 menit dapat mengakibatkan kematian. Karenanya kemampuan mendeteksi gas seperti ini harulah lebih cepat dari kemampuan gas tersebut beraksi dengan tubuh manusia.

4. Stabilitas dan daya tahan, yaitu sejauh mana sensor dapat secara konsisten memberikan besar sensitifitas yang sama untuk suatu gas, serta seberapa lama sensor tersebut dapat terus digunakan.

Jenis sensor kimia ada beberapa macam, yang dikelompokkan berdasarkan cara pendeteksian suatu bahan. Sensor konduktivitas merupakan jenis sensor semikonduktor. Kunci dari teknologi semikonduktor bagi aplikasi dalam dunia sensor adalah jumlah dan mobilitas dari pembawa muatan yang terdapat dalam bahan semikonduktor sangat sensitif tidak hanya terhadap paramater fisik seperti temperatur, cahaya ataupun tekanan, tetapi juga sangat sensitive terhadap parameter kimia.

Sebuah bahan semikonduktor yang dilalui oleh zat kimia tertentu akan mengalami perubahan besaran konduktivitasnya yang jika diubah dalam proses berikutnya mampu mengeluarkan besaran kuantitatif. Sensor semikonduktor merupakan sensor yang banyak diminati dan dipilih kalangan peneliti dikarenakan harganya yang murah, bentuknya yang lebih kecil, serta lebih tahan lama (Venema, 1998). 


\section{METODOLOGI PENELITIAN}

\section{Alat dan Bahan Penelitian}

Alat dan bahan yang dibutuhkan dalam pembuatan alat otomatisasi pengukur kadar vitamin $\mathrm{C}$ dengan metode titrasi asam basa ini, antara lain

Alat : 1. ADC

2. MK AT89S51

3. LCD

4. $\mathrm{pH}$ meter

5. Tempat Infus $500 \mathrm{ml}$

6. Gelas beaker $250 \mathrm{ml}$

7. Sensor konduktivitas

Bahan : 1. Ekstrak vitamin C

\section{2. $\mathrm{NaOH} 0,1 \mathrm{M}$}

3. Aquades.

\section{Langkah-Langkah Titrasi Iodium \\ Pembuatan larutan}

Percobaan ini membutuhkan larutan vitamin $\mathrm{C}$ sebagai larutan yang diuji dengan dua puluh konsentrasi. Sampel yang digunakan adalah ekstrak vitamin C yang akan dilarutkan dengan aquades. Sepuluh konsentrasi tersebut adalah 0,1 gr vitamin $C$ hingga 2 gr vitamin $\mathrm{C}$ yang dilarutkan dengan aquades pada labu ukur hingga mencapai volume 100 $\mathrm{ml}$.

Larutan penguji pada penelitian ini adalah $\mathrm{NaOH} 0,1 \mathrm{M}$ yang dibuat dengan langkah sebagai berikut:

- $\quad$ Timbang $\mathrm{NaOH}$ sebanyak 0,4 gr

- Masukkan dalam labu ukur $100 \mathrm{ml}$ dan beri aquadest sampai tanda yang terdapat dalam labu ukur

\section{Prosedur Kerja}

Dibuat sampel Vitamin C dengan dua puluh konsentrasi yang diinginkan. Setelah itu larutan Vitamin C dimasukkan ke dalam gelas beaker $250 \mathrm{ml}$. Titrasi dengan larutan $\mathrm{NaOH} 0,1 \mathrm{M}$. Akhir titrasi ditandai dengan pembacaan $\mathrm{pH} 7$ pada larutan.

\section{Diagram Blok Sistem}

Berikut ini adalah blok diagram alat secara keseluruhan

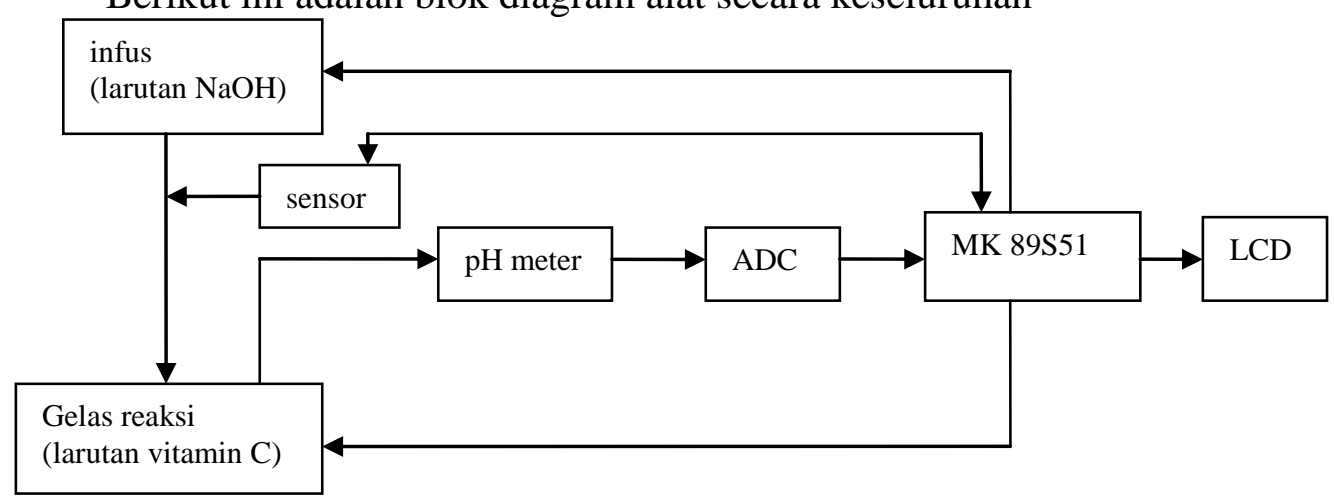

Gambar 1. Blok diagram alat secara keseluruhan

\section{Prinsip Kerja Alat Secara Keseluruhan}

$\mathrm{pH}$ meter dimasukkan ke dalam larutan vitamin $\mathrm{C}$, yang kemudian akan digunakan untuk mengukur tegangan larutan selama proses titrasi asam basa. Keluaran dari pHmeter 
berupa sinyal analog yang masih lemah, kemudian dikuatkan dengan penguat tegangan agar sinyalnya mampu dibaca oleh ADC. Keluaran dari penguat tegangan yang masih merupakan sinyal analog tersebut kemudian di konversikan ke dalam sinyal digital oleh ADC.

Apabila sinyal yang diterima oleh Mikrokontroller telah membaca angka $\mathrm{pH} 7$ hingga lima kali, maka proses titrasi dihentikan. Sedangan sensor konduktivitas berfungsi untuk menghitung tetesan $\mathrm{NaOH}$ yang dibutuhkan selama proses titrasi tersebut berlangsung. Sinyal sensor konduktivitas diterima oleh MK AT89S51 hingga titrasi dihentikan, masukkan dari sensor konduktivitas tersebut dapat diproses untuk menghitung kadar vitamin $\mathrm{C}$ dengan menghitung jumlah tetesan $\mathrm{NaOH}$. Data tersebut kemudian dihitung dan dapat ditampilkan pada LCD.

\section{Teknik Analisis Data}

Pengujian ini akan dibandingkan dengan nilai vitamin $\mathrm{C}$ pada perlakuan titrasi asam basa dengan perhitungan rumus. Sehingga dari perbandingan data tersebut dapat diketahui presentase kesalahan alat pengukur kadar vitamin $\mathrm{C}$ ini.

Analisis data untuk sistem perangkat keras menggunakan analisis prosentase penyimpangan. Persamaan rumus yang digunakan adalah :

$$
\text { penympangan }(\%)=\frac{\text { pengukuran }- \text { perhitungan }}{\text { hasil pengukuran }} \times 100 \%
$$

Keterangan :

Perhitungan $=$ hasil yang terbaca pada LCD

Pengukuran $=$ hasil yang didapat dari pengukuran Spektrofotometer

Sedangkan untuk analisis data yang digunakan untuk sistem secara keseluruhan adalah analisis kesalahan relatif (KR) rata-rata. Adapun persamaan rumus yang digunakan adalah :

$$
\mathrm{KR}(\%)=\frac{\text { hasil pengukuran }- \text { hasil perhitungan alat }}{\text { hasil pengukuran }} \times 100 \%
$$

\section{HASIL DAN PEMBAHASAN}

\section{Hasil dan Pembahasan Pengujian Elektroda pH}

Tujuan dari pengujian elektroda $\mathrm{pH}$ ini adalah untuk mengetahui tegangan yang dihasilkan oleh elektroda pada beberapa larutan buffer. Sehingga dari pengujian ini dapat diketahui ketelitian $\mathrm{pH}$ elektrode dalam membaca nilai $\mathrm{pH}$ pada tiap buffer.

Adapun peralatan dan bahan yang digunakan dalam pengujian elektroda $\mathrm{pH}$ ini adalah sebagai berikut:

1. Elektroda $\mathrm{pH}$

2. Multimeter

3. Larutan buffer $\mathrm{pH} 4,7$ dan 10

4. Gelas beaker $100 \mathrm{ml}$

Prosedur pengujian elektroda $\mathrm{pH}$ yaitu, elektroda diletakkan $\mathrm{pH}$ di dalam gelas beaker yang berisi larutan buffer dan dirangkai alat seperti gambar 4.1 berikut

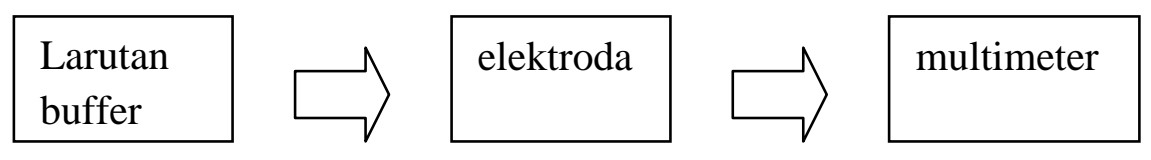

Gambar 2. Blok diagram pengujian elektroda $\mathrm{pH}$ 
1. Diukur tegangan yang dihasilkan oleh elektroda pada larutan buffer $\mathrm{pH} 4,7$ dan 10

2. Diamati dan dicatat tegangan yang dihasilkan elektroda untuk tiap larutan buffer

Perbandingan data hasil pengujian elektroda $\mathrm{pH}$ dengan perhitungan dapat dilihat pada tabel berikut

Tabel 2. Data hasil pengujian elektroda dengan perhitungan

\begin{tabular}{|l|c|c|l|}
\hline $\mathrm{pH}$ & $\begin{array}{c}\text { V uji } \\
(\mathrm{mV})\end{array}$ & $\begin{array}{c}\text { V teori } \\
(\mathrm{mV})\end{array}$ & $\begin{array}{c}\text { Selisih } \\
(\mathrm{D})\end{array}$ \\
\hline 4 & 170 & 177 & 7 \\
\hline 7 & 10 & 0 & 10 \\
\hline 10 & -188 & 177 & 11 \\
\hline
\end{tabular}

Dari data hasil pengujian mempunyai perbedaan dengan nilai dari perhitungan sebesar

$$
\begin{aligned}
\text { \%error } & =\frac{\overline{\mathrm{D}}}{\mathrm{FS}} \times 100 \% \\
& =\left[\frac{9,33}{414}\right] \times 100 \% \\
& =2,25 \%
\end{aligned}
$$

Dimana, $\bar{D}=$ Rata-rata selisih

FS = skala penuh elektroda sebesar $414 \mathrm{mV}$

Adanya kesalahan ini disebabkan karena beberapa faktor, diantaranya:

1. Pengaruh suhu pada saat pengujian tidak tepat sama dengan $25^{\circ}$. Adapun karakteristik elektroda ini mempunyai kesalahan suhu mendekati $0,003 \mathrm{pH} /{ }^{\circ} \mathrm{C}$ dari $\mathrm{pH}$ 7(eutch instrument)

2. Pengaruh sisa dari pengukuran sebelumnya. Larutan buffer yang masih menempel di permukaan elektroda.

3. Terdapat benda bermuatan logam disekitar $\mathrm{pH}$ Elektrode

Dari tabel 4.1 yang telah kita dapatkan, dapat diketahui bahwa $\mathrm{pH}$ meter tersebut mampu membaca nilai $\mathrm{pH}$ sesuai dengan teori. $\mathrm{pH}$ meter yang dicelupkan ke dalam $\mathrm{pH}$ buffer 7, maka nilai voltasenya mendekati nol, sedangkan ketika $\mathrm{pH}$ meter dicelupkan pada $\mathrm{pH}$ buffer 4, nilai voltasenya $177 \mathrm{mV}$. Hal ini terjadi karena pada $\mathrm{pH} 4$ larutan bersifat asam, dan telah kita ketahui bahwa nilai hantar larutan asam tinggi.

PH meter adalah salah satu jenis sensor kimia, karena mampu mendeteksi atau menangkap fenomena berupa nilai $\mathrm{pH}$ pada zat kimia yang diuji. Sistem kerja pada $\mathrm{pH}$ meter yaitu, ketika $\mathrm{pH}$ meter dicelupkan pada larutan vitamin $\mathrm{C}$, maka $\mathrm{pH}$ meter mengubah sifat kimia yang dideteksinya menjadi sinyal elektrik. Sensor $\mathrm{pH}$ meter merk PE-03 ini sangat sensitif dalam mendeteksi nilai $\mathrm{pH}$ pada larutan kimia yang diuji dan sangat peka terhadap perubahan suhu pada ruangan. pada Saat menjalankan alat ini, suhu ruangan diusahakan setara dengan suhu kamar normal yaitu $25^{\circ} \mathrm{C}$.

\section{Pengujian Sistem Secara Keseluruhan}

\section{Gambar Alat Secara Keseluruhan Beserta Fungsinya}

Berikut adalah gambar sistem alat otomatisasi pengukur kadar vitamin $\mathrm{C}$ dengan metode titrasi asam basa yang ditunjukkan pada gambr 4.5. Secara umum, rangkaian alat ini terdiri dari dua bagian yaitu perangkat elektronik dan perangkat titrasi. 


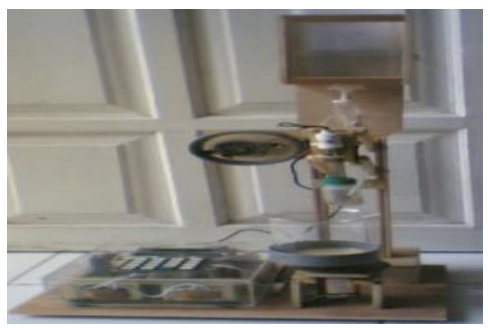

Gambar 3. Rangkaian alat secara keseluruhan

\section{Rangkaian Elektronik}

Rangkaian elektronik ini berfungsi untuk mengendalikan sistem rangkaian titrasi secara keseluruhan. Untuk mengendalikan rangkaian secara keseluruhan, maka pada sistem ini ditanamkan software uang mampu menghitung kadar vitamin $\mathrm{C}$ pada suatu larutan yang diuji. Rangkaian ini terdapat masukkan dari catu daya dan LCD LMB162AFC. Catu daya berfungsi sebagai masukkan yang digunakan untuk menjalankan alat tersebut.

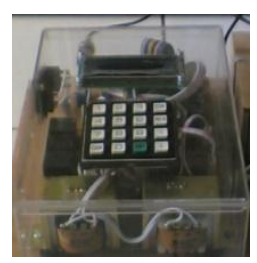

Gambar 4. Rangkaian elektronik

LCD LMB162AFC berfungsi untuk mengatur acuan nilai yang digunalan untuk menghentikan proses titrasi berupa pembacaan nilai ADC pada $\mathrm{pH} 7$ serta menampilkan hasil akhir nilai kadar vitamin $\mathrm{C}$ dalam 5 digit dengan satuan mg. Pada LCD tersebut, terdapat beberapa tombol yang memiliki fungsi yang berlainan. Berikut ini adalah fungsi dari masing-masing tombol pada keypad

1) Tombol angka $1 . . .10$, berfungsi untuk mengisi nilai acuan yang digunakan untuk menghentikan proses titrasi. Nilai acuan ini di dapat dari pembacaan $\mathrm{pH}$ buffer 7

2) Tombol "cor", berfungsi untuk memasukkan nilai acuan yang digunakan.

3) Tombol "can", berfungsi untuk mengcancel proses titrasi atau keluar dari menu

4) Tombol "men", berfungsi untuk melihat nilai larutan yang terbaca pada ADC.

\section{Rangkaian Titrasi}

Rangkaian titrasi ini terdiri dari tiga sistem secara keseluruhan

1) Rangkaian Titran

Rangkaian ini memiliki fungsi untuk meneteskan $\mathrm{NaOH}$ (titran) pada larutan asam askorbat. Rangkaian ini terdiri dari sebuah infus yang volume tiap tetesnya setara dengan $\frac{1}{16} \mathrm{ml} \mathrm{NaOH}$. Tiap tetesan akan dideteksi oleh rangkaian sensor konduktivitas yang terdapat pada bagian bawah infus. Infus tersebut dikendalikan oleh rangkaian katup. $\mathrm{NaOH}$ akan menetes sebanyak empat kali setiap katup terbuka

2) Rangkaian Katup

Rangkaian katup terdiri dari sebuah katup yang dikendalikan oleh relay pada rangkaian elektronik. Rangkaian ini berfungsi untuk mengendalikan tetesan $\mathrm{NaOH}$. Pada proses titrasi, jika katup terbuka maka $\mathrm{NaOH}$ akan menetes. Sedangkan bila katup tertutup, maka $\mathrm{NaOH}$ tidak menetes. Selama proses titrasi, katup tertutup beberapa detik agar larutan $\mathrm{NaOH}$ dan Vitamin $\mathrm{C}$ pada gelas beaker tercampur secara rata. Katup ini akan berhenti membuka ketika $\mathrm{pH}$ yang terbaca oleh sistem elektronik membaca nilai acuan pada larutan. 


\section{3) Rangkaian Titer}

Rangkaian titer terdiri dari $\mathrm{pH}$ elektrode, selang infus dan gelas beaker. $\mathrm{pH}$ elektrode berfungsi sebagai sensor $\mathrm{pH}$ yang digunakan untuk mengukur nilai $\mathrm{pH}$ yang terdapat pada larutan . Selang infus diatur sedemikian rupa sehingga tetesan $\mathrm{NaOH}$ tidak mengenai sensor $\mathrm{pH}$ tersebut, sedangkan gelas beaker disini berfungsi sebagai tempat titrasi dan tempat titer (larutan yang diuji). Pada saat titrasi berlangsung, gelas beaker tersebut akan berputar satu arah yang putarannya dikendalikan oleh rangkaian elektronik.
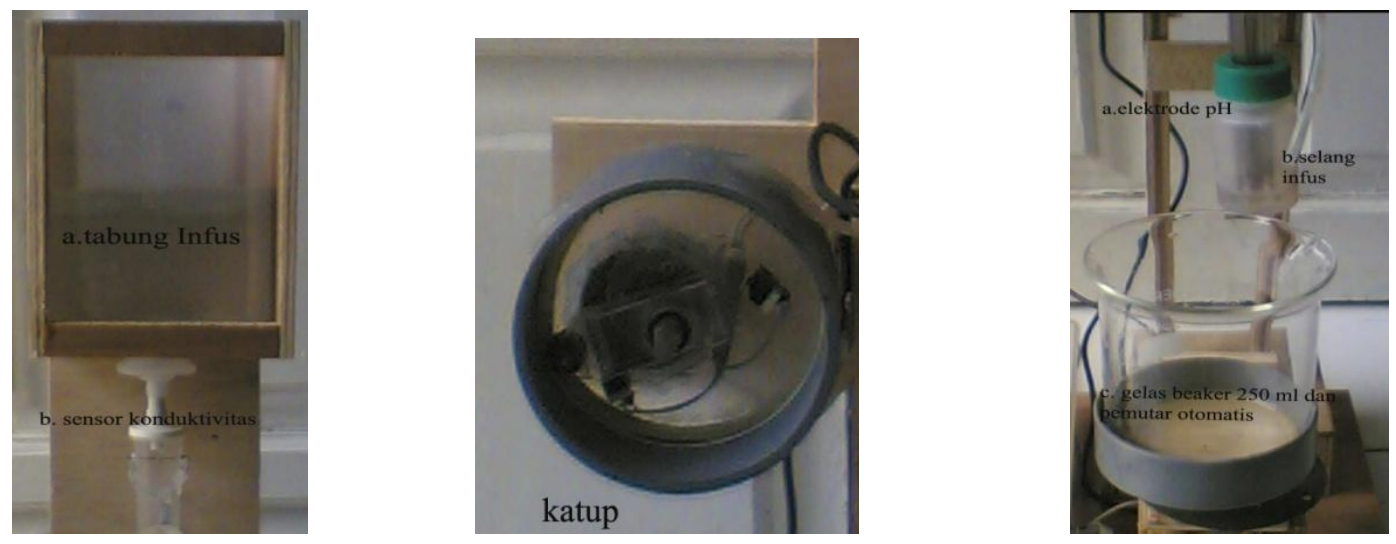

Gambar 5 .a) Rangkaian titran, b) Rangkaian katup, dan c) Rangkaian titer .

\section{Pembuatan sampel dan kalibrasi elektrode $\mathbf{p H}$ \\ Pembuatan Sample}

Alat otomatisasi pengukur kadar vitamin $\mathrm{C}$ ini menggunakan sampel larutan Vitamin $\mathrm{C}$ yang nantinya akan diuji pada alat tersebut agar diketahui ketepatan niali pembacaannya. Sampel yang digunakan untuk penelitian ini adalah ekstrak Vitamin C murni. Pada penelitian ini dibuat sepuluh sample yang dilarutkan dengan aquadest hingga $100 \mathrm{ml}$. Langkah pembuatan sampel

a.Sampel ditimbang menjadi sepuluh bagian yang bervariasi dengan menggunakan neraca analitik, dimulai dari $100 \mathrm{mg}$ hingga $2000 \mathrm{mg}$

b.Sampel dimasukkan dalam labu ukur $100 \mathrm{ml}$ dan beri aquades sampai tanda yang terdapat pada labu ukur

c. Sampel damasukkan ke dalam botol kaca dan diberi label sesuai dengan berat sampel tersebut dan tutup rapat agar Vitamin $\mathrm{C}$ tidak mudah teroksidasi

Selain pembuatan sampel, dibuat pula Titer yang memiliki konsentrasi $0,1 \mathrm{M}$. Titer tersebut dibuat dari $\mathrm{NaOH}$ yang dilarutkan dengan aquadest dalam gelas ukur $100 \mathrm{ml}$. Adapun langkah pembuatannya sama seperti pembuatan sampel Vitamin C. Untuk mengetahui kadar bahan yang digunakan untuk mencapai konsentrasi $0,1 \mathrm{M}$ dapat dihitung denga rumus molaritas sebagai berikut

$$
M=\frac{g r / m r N a O H}{V}
$$

Keterangan :

$\mathrm{M}=$ Nilai molaritas yang diinginkan $(0,1 \mathrm{M})$

$\mathrm{mr}=$ nilai $\mathrm{mr} \mathrm{NaOH}$ adalah 40

$\mathrm{V}=$ Volume yang digunakan untuk melarutkan $\mathrm{NaOH}(0,1$ liter $)$

gr = berat $\mathrm{NaOH}$ yang dibutuhkan untuk membuat konsentrasi $0,1 \mathrm{M}$

Dari rumus diatas maka $\mathrm{NaOH}$ yang dibutuhkan untuk membuat konsentrasi $0,1 \mathrm{M}$ adalah 


$$
\begin{aligned}
\mathrm{gr} & =\mathrm{M} \times \mathrm{mr} \times \mathrm{V} \\
& =0,1 \times 40 \times 0,1 \\
& =0,4 \mathrm{gr} \mathrm{NaOH}
\end{aligned}
$$

\section{Kalibrasi pH Elektrode}

Kalibrasi $\mathrm{pH}$ digunakan agar nilai $\mathrm{pH}$ stabil pada saat digunakan dalam mengukur kadar vitamin $\mathrm{C}$ pada larutan sample. Langkah kalibrasi elektrode $\mathrm{pH}$ PE-03 adalah sebagai berikut :

1. Botol pada $\mathrm{pH}$ dibuka dan dicuci dengan aquadest, keringkan dengan tissue

2. $\mathrm{pH}$ meter dimasukkan dalam $\mathrm{pH}$ buffer 4 hingga nilai ADC yang terbaca pada LCD stabil, setelah itu dicuci dengan aquadest dan keringkan dengan tissue

3. $\mathrm{pH}$ meter dimasukkan pada $\mathrm{pH}$ buffer 7 hingga nilai ADC yang terbaca stabil, setelah itu cuci dengan aquadest, keringkan dengan tissue

4. $\mathrm{pH}$ meter siap digunakan

\section{Pengujian Sistem Keseluruhan}

Alat pengukur kadar vitamin $\mathrm{C}$ ini menggunakan prinsip titrasi asam basa, yaitu dengan cara meneteskan larutan basa yaitu $\mathrm{NaOH}$ yang berfungsi sebagai titran yang diteteskan pada larutan bersifat asam Vitamin $\mathrm{C}$ yang berfungsi sebagai Titer. Sistem kerja alat ini yaitu menghitung volume $\mathrm{NaOH}$ yang dibutuhkan untuk menetralkan larutan Asam Askorbat sehingga $\mathrm{pH}$ pada larutan menjadi netral.

Sebelum melakukan perhitungan, terlebih dahulu catu daya yang terdapat pada rangkaian elektronik dinyalakan. Setelah itu, kalibrasikan elektroda $\mathrm{pH}$ dengan $\mathrm{pH}$ buffer 4 dan 7. Setting nilai acuan pada ADC dengan menggunakan tombol "cor" pada LCD. Nilai acuan bergantung pada nilai ADC yang terbaca pada $\mathrm{pH}$ buffer 7. Pada titrasi Asam Basa kuat, proses titrasi terhenti pada saat PH 7 atau netral. Hal itu disebabkan karena pada pH tersebut larutan asam tepat mengikat larutan basa. Setelah nial acuan dimasukkan dalam LCD, masukkan larutan sample pada gelas beaker $250 \mathrm{ml}$ dan celupkan elektrode $\mathrm{pH}$ pada larutan. Tekan enter pada LCD hingga proses titrasi berjalan.

Pada saat proses titrasi berjalan, maka secara otomatis gelas beaker berputar satu arah yang sesuai dengan prinsip dalam menjalankan titrasi. Sistem titran dan katup pun bekerja secara otomatis. Hal ini dapat kita lihat bahwa pada saat titrasi berlangsung, larutan $\mathrm{NaOH}$ menetes karena katup yang menyumbat selang infus terbuka. Katup tak selalu terbuka pada saat titrasi, katup menutup selama empat detik sebelum membuka kembali selang infus. Hal ini dilakukan agar larutan $\mathrm{NaOH}$ tercampur rata dengan Asam Askorbat.

Sensor konduktivitas yang digunakan berfungsi untuk menghitung tetesan $\mathrm{NaOH}$ pada saat titrasi hingga proses tersebut terhenti. Keluaran dari sensor tersebut hanya dua yaitu 0 dan 1 . Nilai 0 pada saat $\mathrm{NaOH}$ tidak menetes sedangkan nilai 1 pada saat $\mathrm{NaOH}$ menetes. Tiap tetesan pada saat proses titrasi dihitung oleh sistem mikrokontroller dan disimpan sebagai masukkan.

Tampilan pada LCD pada saat titrasi adalah nilai acuan (dari $\mathrm{pH}$ buffer 7) dan nilai ADC yang terbaca pada larutan. Pada saat titrasi berlangsung, terlihat bahwa nilai ADC yang ditampilkan tidak stabil. Hal itu terjadi karena larutan belum tercampur rata, sehingga elektrode $\mathrm{pH}$ membaca nilai asam dan basa. Range ADC yang terbaca yaitu \pm 120 . Alat ini berhenti setelah elektrode $\mathrm{pH}$ lima kali membaca acuan yang telah ditetapkan. Hal ini dilakukan untuk meningkatkan keakuratan pembacaan $\mathrm{pH}$ larutan oleh elektrode $\mathrm{pH}$.

Rumus yang digunakan untuk menghitung kadar vitamin $C$ yaitu

$$
\begin{aligned}
& \mathrm{M}_{1} \mathrm{~V}_{1}=\mathrm{M}_{2} \mathrm{~V}_{2} \\
& M_{2}=\frac{\mathrm{gram} / \mathrm{mr}}{V_{2}}
\end{aligned}
$$


Keterangan :

M1 $=0.1 \mathrm{Mol}$ (Molaritas Larutan Penguji)

V2 $=0,1 \mathrm{~L}$ (Volume Larutan yang diuji)

M2 = Molaritas Larutan yang diuji

$\mathrm{V} 1=\mathrm{I} \times \mathrm{T}$

I $\quad=$ Banyaknya proses penetesan

$\mathrm{T} \quad=1 / 16$ (Volume/tetes)

$\mathrm{Mr}$ asam askorbat $=176$ dan larutan yang dilakukan uji coba yaitu Asam askorbat dan $\mathrm{NaOH} 0.1 \mathrm{M}$

Hasil perhitungan kesalahan relatif menunjukkan tingkat akurasi atau ketelitian dalam penelitian ini kurang bagus karena ada beberapa faktor antara lain, tegangan yang digunakan sebagai masukkan daya tidak stabil sehingga pengukuran pun menjadi tidak stabil. Faktor lain yang mempengaruhi yaitu gelas beaker yang digunakan membuat Asam Askorbat (Vitamin C) mudah teroksidasi, hal ini menyebabkan nilai yang terukur sebelum titrasi dan sesudah proses titrasi berbeda.

Meskipun nilai kesalahan relatif yang didapatkan besar, namun nilai pembacaan vitamin $\mathrm{C}$ pada alat otomatisasi pengukur kadar viatamin $\mathrm{C}$ ini tidak jauh berbeda dengan pembacaan pada alat yang memiliki tingkat keakurasian tinggi seperti spektrofotometer.

\section{Analisis Data Penelitian}

Percobaan Alat

Untuk mengetahui hasil dari proses pengukuran kadar Vitamin $\mathrm{C}$ dari alat tersebut, maka penulis melakukan percobaan pada alat dimana sistem dapat berjalan sesuai dengan rencana. Percobaan alat dilakukan oleh sampel ekstrak vitamin $\mathrm{C}$ dan data hasil percobaan alat sebagai perbandingan dengan hasil pembacaan kadar vitamin $\mathrm{C}$ pada spektrofotometer.

\section{Data Hasil Penelitian}

Berikut ini adalah tabel pengukuran kadar Vitamin $\mathrm{C}$ dengan menggunakan alat titrasi. Data tersebut diambil dari 20 sampel larutan ekstrak vitamin C murni yang telah dititrasi dengan larutan $\mathrm{NaOH}$ dengan konsentrasi se0,1 M. Untuk mengetahui besar kesalahan relatif alat tersebut, maka hasil pengukuran kadar vitamin $\mathrm{C}$ pada alat dibandingkan dengan hasil penguikuran kadar vitamin $\mathrm{C}$ pada alat yang standartnya lebih tinggi yaitu spektrofotometer. 
Tabel 3. Kesalahan Relatif pengukuran

\begin{tabular}{|l|l|l|l|}
\hline \multirow{2}{*}{ No } & \multicolumn{2}{|c|}{ Nilai Kadar Vitamin C } & \multirow{2}{*}{ KR (\%) } \\
\cline { 2 - 3 } & Hasil spektrofotometer & Hasil Pengukuran & \\
\hline 1 & 100 & 103,86 & 3,86 \\
\hline 2 & 205 & 193,76 & 5,84 \\
\hline 3 & 301 & 309,88 & 2,9 \\
\hline 4 & 400 & 397,15 & 0,7125 \\
\hline 5 & 500 & 513,67 & 2,734 \\
\hline 6 & 599 & 600,95 & 0,325 \\
\hline 7 & 700 & 707,36 & 1,051 \\
\hline 8 & 802 & 800,44 & 0,1945 \\
\hline 9 & 894 & 904,87 & 1,215 \\
\hline 10 & 1005 & 1011,67 & 0,633 \\
\hline 11 & 1100 & 1118,03 & 1,64 \\
\hline 12 & 1200 & 1204,13 & 0,344 \\
\hline 13 & 1300 & 1308,54 & 0,657 \\
\hline 14 & 1400 & 1411,17 & 0,792 \\
\hline 15 & 1500 & 1500,28 & 0,61 \\
\hline 16 & 1597 & 1606,06 & 1,815 \\
\hline 17 & 1702 & 1708,96 & 2,11 \\
\hline 18 & 1800 & 1805,87 & 0,326 \\
\hline 19 & 1905 & 1893,33 & 0,612 \\
\hline 20 & 2000 & 2013,82 & 1,191 \\
\hline \multicolumn{2}{|l|}{$\%$ Kesalahan rata-rata } & 1,4601 \\
\hline
\end{tabular}

$K R(\%)=\left|\frac{\text { data alat spektrofotometer }- \text { data alat penelitian }}{\text { hasil pengukuran }}\right| x 100 \%$

Dari data tersebut dapat dibuat grafik perbandingan nilai pengukuran Vitamin C pada alat dengan spektrofotometer dan pengukuran dengan alat penelitian. Kedua data tersebut menghasilkan sebuah grafik linier yang ditunjukkan pada gambar 4.8 yang dengan persamaan $\mathrm{y}=99,99 \mathrm{x}+0,578$. Persamaan tersebut dapat digunakan sebagai konversi perhitungan kadar vitamin $\mathrm{C}$ pada alat penelitian dengan perhitungan kadar viatmin $\mathrm{C}$ pada spektrofotometer

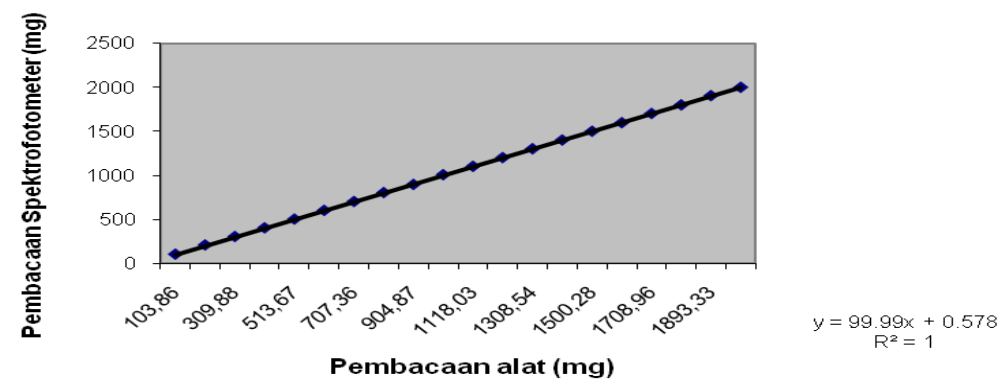

Gambar 6. Grafik perbandingan pengukuran alat dan spektrofotometer

\section{Analisis Data Hasil Penelitian}

Dari data yang di dapat, dapat diketahui kesalahan relatif pada alat yaitu sebesar $1,4601 \%$ menurut statistik, hasil ini cukup baik dan masih memenuhi persyaratan yang ditentukan yaitu kesalahan relatif lebih kecil dari $5 \%$. Kesalahan tertinggi terdapat pada pembacaan kadar vitamin C $200 \mathrm{mg}$ dengan nilai kesalahan relatif sebesar 5,84\%. 
Sedangkan kesalahan terkecil terdapat pada pembacaan kadar vitamin $600 \mathrm{mg}$ dengan kesalahan sebesar 0,325\%.

Data tersebut menghasilkan sebuah grafik yang linier dengan persamaan $\mathrm{y}=$ $99,99 x+0,578$ yang ditunjukkan pada gambar 4.8. Persamaan ini menunjukkan bahwa data pada pembacaan data pada alat mendekati pembacaan data pada spektrofotometer. Persamaan ini berfungsi untuk mengkonversikan pengukuran pada alat dengan pengukuran yang terbaca pada spektrofotometer.

Alat ini mampu mengukur kadar vitamin C hingga 9999,99 mg. Adapun kesalahan relatif sebesar 1,4601\% disebabkan oleh beberapa faktor, diantaranya proses pembuatan larutan sample yang tidak sesuai dengan prosedur, pencucian $\mathrm{pH}$ yang kurang bersih, penyimpanan larutan dan wadah titrasi yang menyebabkan mudahnya larutan vitamin $\mathrm{C}$ teroksidasi sehingga kadar vitamin $\mathrm{C}$ pada larutan berubah.

\section{Kesimpulan}

Dari hasil penelitian dan pembahasan tentang Alat otomatisasi Pengukur Kadar Vitamin C Menggunakan Metode Titrasi Asam Basa yang telah diuraikan maka dapat ditarik kesimpulan sebagai berikut:

Alat pengukur kadar Vitamin C dengan metode tirasi asam basa ini dapat bekerja dengan baik. Alat ini dapat menjalankan titrasi secara otomatis seperti meneteskan dan menghentikan titran, mengaduk larutan, mengukur larutan serta menghitung kadar viatmin $\mathrm{C}$ secara otomatis. Alat otomatisasi titrasi ini dapat membaca masukkan nilai titer pada proses titrasi asam basa menggunakan sensor konduktivitas sebagai masukkannya.

Pembuatan perangkat lunak dari alat ini dapat menghitung kadar vitamin C (Asam Askorbat) pada larutan. Data masukkan alat ini adalah banyaknya titer yang dibutuhkan selama proses titrasi. Data tersebut digunakan untuk menghitung kadar Vitamin $\mathrm{C}$ dengan menggunakan persamaan mol $\mathrm{NaOH}=$ mol Asam Askorbat.

\section{DAFTAR PUSTAKA}

Almatsier, Sunita. 2003. Prinsip Dasar Ilmu Gizi. Jakarta : Gramedia

Day, R.A. 1986. Analisis Kimia Kuantitatif. Jakarta: Erlangga

Helrich, Kenneth. 1990. Official Methods Of Analysis Of Association Of Official Analytical Chemist Volume Two. USA : Association Of Official Analytical

Naidu, K Akhilender. 2003. Nutrition Journal..india: BioMed Central) Nutrition Journal 2003, 2:7

Natsir, Arsyad. 2001.Kamus Kimia dan Penjelasan Ilmiah. Jakarta : Gramedia Pustaka Utama

Sastrohamidjojo, Hardjono. 2005. Kimia Dasar. Yogyakarta : UGM PRESS

Soebagio. 2005. Kimia Analitik II. Malang :UM Press

Sudarmaji, Slamet dkk. 2007. Prosedur Analisa Untuk Bahan Makanan dan Pertanian (edisi keempat). Yogyakarta: Liberti

Sutrisno. 1987. Ektronika 2 Teori dan Penerapannya. Bandung : ITB

Sukardjo. 2002. Kimia Fisika. Jakarta : Rineka Cipta

Tim lab. 2007. Pemrograman mikrokontroller AT89S51 dengan $\mathrm{C} / \mathrm{C}++$ dan Assembler. Yogyakarta : Andi

Venema, Adrian. 1998. Principles of Chemical Microsensors, Lecture Notes at Delft University of Technology,

Wijanarko, Simon Bambang. 2002. Analisa Hasil Pertanian. Malang: Universitas Brawijaya

Winarno, F.G. 2002. Kimia Pangan dan Gizi. Jakarta: Gramedia 
Woollard, Barry. diindonesiakan oleh: H.Kristono. 2006. Elektronika Praktis. Jakarta: Pradnya Paramita

www.100y.com.tw Lutron Electronic (datasheet diakses tgl 23 Maret 2009) www.atmel.com (diakses tgl 5 Desember 2008)

www.national.com. National Semiconductor 2002 (diakses tgl 8 April 2009) www. Robotindonesia.com (diakses tgl 26 Januari 2009) 